\title{
16. PALYNOLOGY OF LEG 28 DRILL SITES, DEEP SEA DRILLING PROJECT
}

\author{
Elizabeth M. Kemp, ${ }^{1}$ Bureau of Mineral Resources, Canberra, Australia
}

\begin{abstract}
Palynological examination has been made of a total of 101 core samples from Sites 264, 266, 268, 270, and 274 from Leg 28.

At Site 270, preglacial carbonaceous and glauconitic sand units yielded few palynomorphs, except for a sparse assemblage of Oligocene dino-flagellate cysts from the greensand unit. In the overlying glacial-marine unit at this site, basal sediments of late Oligocene age yielded spore and pollen assemblages which seem likely to be in situ, rather than recycled. These assemblages are dominated by Nothofagidites, with subsidiary podocarpaceous,.proteaceous, and myrtaceous pollen, and suggest a parent vegetation showing little floristic change from that known from Eocene erratic siltstones at McMurdo Sound. It is suggested that such vegetation persisted into the earliest phases of glaciation. The same units yieldpd rare dinoflagellate cysts, including Selenopemphix nephroides, a form which has hitherto only been recorded from the mid to late Oligocene of northwest Europe.

Basal silty units at Site 274 yielded rich dinoflagellate assemblages, probably of late Eocene age. Several species of this assemblage persist into the overlying diatom-rich unit of Oligocene age. The dinoflagellate suites are similar to those from the McMurdo erratics and to those from the Rio Turbio Formation of Patagonia and form part of a distinctive austral floral province.

Very little palynological material, apart from abundant leiospheres, was recovered from the pelagic Sites 264 and 266 and from the near-continent Sites 268 and 269 . The scarcity of palynomorphs at these sites may be due to excessive dilution by pelagic remains and terrigenous detritus.
\end{abstract}

\section{INTRODUCTION}

A program of palynological investigations of cores recovered from selected Leg 28 drill sites (Figure 1) was undertaken with three basic aims.

1) To provide age determinations by means of palynomorphs (chiefly dinoflagellate cysts) in sequences where other microfossils were absent or nondiagnostic as to age.

2) To provide new data on the stratigraphic range of dinoflagellate species and on their geographic distribution in Tertiary sediments of high southern latitudes.

3) To examine pollen and spore assemblages from early Tertiary sequences close to Antarctica and to see what light these might shed on the floral history of that continent. Changes in vegetation must reflect climatic events affecting the region; in the case of Antarctica, the most dramatic of these is the temperature drop of the Paleogene, which culminated in the growth of an ice cap to continental proportions. Such an event must have

'Formerly: Department of Geology, Florida State University, Tallahassee, Florida. been predated by the elimination of vegetation on the continent, the dating of which by palynological means ideally should provide another means of dating the advent of the continental ice cap.

\section{Age Determination}

The basal sections of sequences penetrated at Sites $268,269,270$, and 274 yielded sparse and poorly preserved siliceous and calcareous microfossils, making age determinations difficult. Suites of core samples from the lower units at these sites were therefore macerated to recover acid-insoluble fossils.

At Sites 268 and 269 the lowest lithologic units proved nearly barren of dinoflagellate cysts, spores, or pollen, but swarms of acritarch species occur in the lowest core at Site 268. These, however, are long-ranging, generalized types. The apparently barren nature of these intervals may be due to excessive dilution of microfossils by terrigenous detritus.

At Site 270, attempts were made to recover palynomorphs from the carbonaceous sandstone and calcareous greensand units at the base of the sedimentary sequence, as well as from the overlying thick, glacial-marine units. The carbonaceous sandstone (Unit 4) yielded no palyno-morphs, although large 


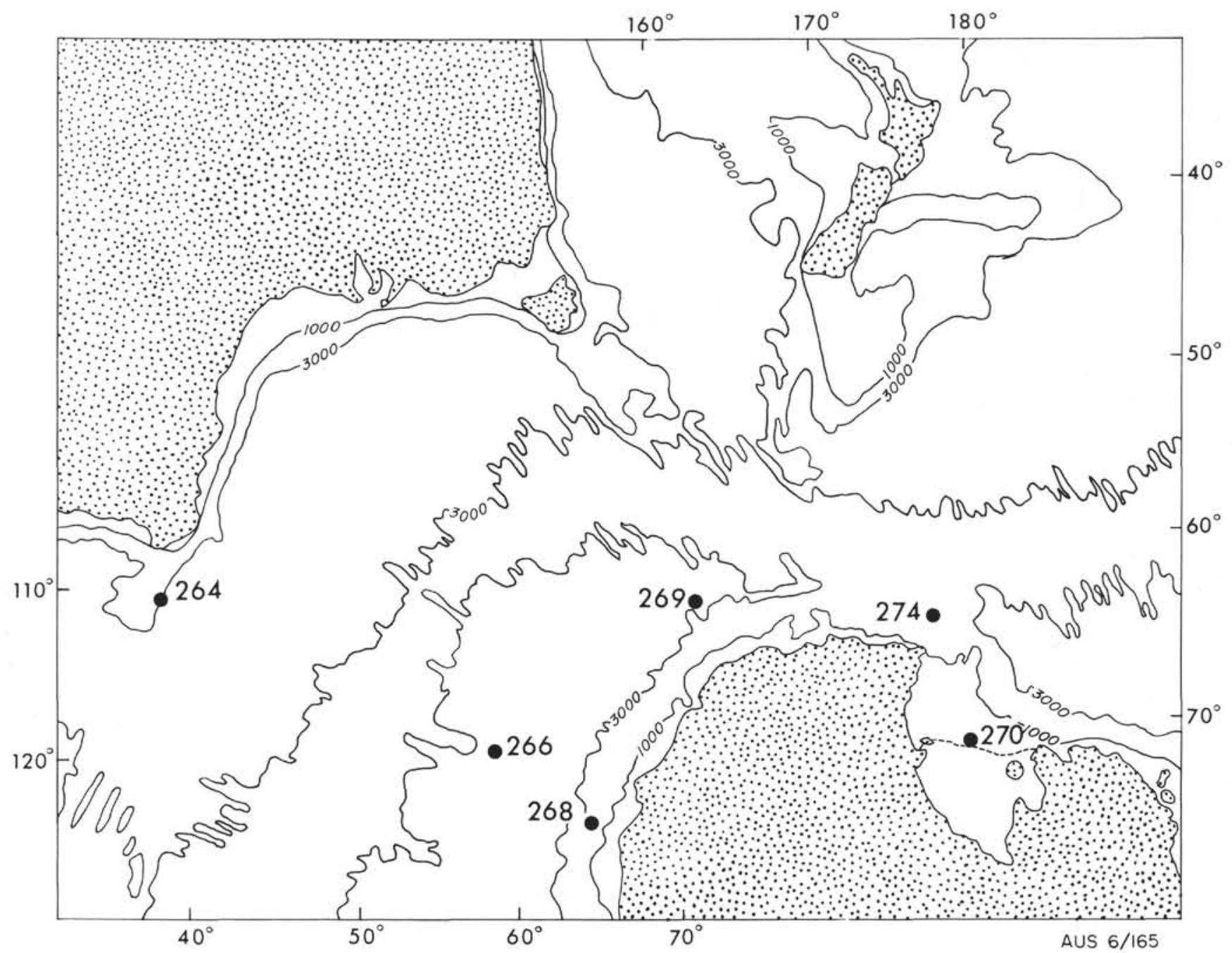

Figure 1. Locality map showing Leg 28 drill sites sampled palynologically. 1000 meter and 3000 meter isobaths shown.

woody fragments are abundant. The absence of spores, pollen, and dinoflagellate cysts is probably due to the winnowing of the silt-sized fraction in a shallow-water depositional environment.

The calcareous greensand (Unit 3) has been dated as 26 m.y. by $\mathrm{K}-\mathrm{Ar}$ methods (see McDougall, this volume). Maceration of about $40 \mathrm{~g}$ of the greensand yielded a sparse assemblage of dinoflagellatecysts. These include the cyst species Deflandrea macmurdoensis Wilson, $D$. asymmetrica Wilson, and Areosphaeridium diktyoplokus (Klumpp), which are known from late Eocene strata in South America and Europe, with possible extensions of their ranges into the Oligocene. The distinctive species Selenopemphix nephroides Benedek is also present and has a known range of mid to late Oligocene. Assessment of the known ranges of all species suggests an Oligocene age for the unit; greater precision in age determination is not possible with current information.

The lowest section of the overlying glacial-marine unit at Site 270 (Subunit 2J of Unit 2) contains abundant pollen, all of which belong to long-ranging form species. Some dinoflagellate cysts are present, including $S$. nephroides, the occurrence of which suggests that the time break between the greensand and the overlying silty claystones of glacial origin is of relatively short duration.

At Site 274, palynological sampling was concentrated in Unit 5, the lowest sedimentary unit, which is a silty claystone with some chert horizons. Tentative dating by sparse foraminifera suggests an age as old as Eocene for this unit, and Cretaceous forms were recorded just above basement. Rich dinoflagellate cyst assemblages were recovered from nearly all cores of Unit 5. The assemblages are similar in composition to those described from erratics in moraines at McMurdo Sound by Wilson (1967a); similar suites occur in southern South America (Archangelsky, 1969).

The stratigraphically most significant forms in the assemblage include Areosphaeridium diktyoplokus (Klumpp), Leptodinium dispertitum Cookson, Deflandrea cf. oebisfeldensis Eisenack, D. granulata Menendez, D. macmurdoensis Wilson, D. asymmetrica Wilson, Turbiosphaera filosa (Wilson), Spinidinium aperturum Wilson, and Thalassiphora $\mathrm{cf}$. pelagica (Eisenack). Comparison with South American assemblages, and with the ranges of those few species which occur in Europe and 
Australia, suggests a late Eocene age for the unit, although an early Oligocene age cannot be entirely ruled out.

\section{Stratigraphical and Geographical Distribution Data}

Samples from Sites 264 and 266 were macerated specifically in the hope of obtaining dinoflagellate sequences from closely dated pelagic sediments ranging in age from early Eocene through Pliocene. However, for reasons that are obscure, none of the samples was productive. At Site 264, where a full Eocene sequence of nannoplankton ooze and chalk is present, the absence of palynomorphs from the 10 cores sampled may be due to either deposition under oxidizing conditions or to extreme dilution of these microfossils by calcareous algal skeletons. Good assemblages of dinoflagellate cysts have, however, previously been recov-ered from coccolith oozes (Habib, 1972).

At Site 266 samples from 16 cores were macerated, but only that from Core 9 (Pliocene) yielded any palynomorphs, and these were chiefly acritarchs of simple morphology. It may be that high rates of pelagic sedimentation at this site have resulted in dilution of the dinoflagellate cysts that may have been present.

The presence of elements of a dinoflagellate suite hitherto regarded as Eocene in what has been firmly dated as an Oligocene diatom-rich section at Site 274 is note-worthy. The presence of Aiora fenestrata, Areosphaeridium diktyoplokus, Spinidinium aperturum, and Deflandrea asymmetrica high in Unit 4 at this site appears to represent a genuine extension of the known range of these species into the Oligocene. The possibility of their having been recycled cannot be entirely discounted, but there is no other evidence to support such a reworked origin, and some of the most delicate of these forms are extremely well preserved.

The rich suite of dinoflagellate cysts in Unit 5 at Site 274 appears, on present evidence, to belong to a distinct late Eocene floral province which is restricted to high southern latitudes. It is identical with that from the McMurdo erratics and has at least 10 species in common with South American assemblages. The assemblages contain a group of species which appear to be endemic to southern near-polar regions, notably; Deflandrea macmurdoensis, D. asymmetrica, D. granulata, D. oebisfeldensis sensu Cookson and Cranwell, Spinidinium aperturum (and the possibly overlapping $S$. rotundum), and Turbiosphaera filosa. Characteristic elements which are nonendemic include $A$. diktyoplokus, $T$. cf. pelagica, and $A$. fenestrata. A high relative frequency of Hystrichosphaera ramosa also distinguishes these assemblages.

Geographically, the nearest late Eocene assem-blages to those of the Ross Sea are those of the South Island of New Zealand, from which Wilson (1967b) described Wetzeliella species. The overall composition of these assemblages is comparable to those known from southeastern Australia (Wilson, written communication, 1974), including those of the Brown's Creek Clays of Victoria (Cookson, 1965a, b). Assemblages from both these regions differ markedly from that at Site 274 , being characterized by a high proportion of chorate cysts, notably by forms with a reflected tabulation expressed by processes arranged in annular fashion, as in the genera Systematophora and Schematophora. A single species, Leptodinium dispertitum, is common to both the Australian and Antarctic suites.

European assemblages from Eocene sediments are likewise very different from those of high southern latitudes. Most comprehensive studies of European suites, however, have been made on early Eocene material. Gocht's (1969) account of assemblages from northwest Germany concentrates on early Eocene sequences, but makes mention of problematic late Eocene and of mid Oligocene sections. All are dominated by chorate cysts and by a diversity of Wetzeliella species. Assemblages referred to as early Oligocene by Eisenack (1954), and which are possibly referable to the late Eocene, show the same diversity of Wetzeliella and of chorate cyst forms. Only $A$. diktyoplokus and $T$. pelagica are held in common with assemblages from the far south.

\section{Tertiary Vegetational History of Antarctica}

Initially, it was hoped that Site 270 , close to the present Ross Ice Shelf, would pass through a substantial sedimentary sequence recording the change from preglacial to full continental glacial conditions. The presence of preglacial Tertiary sediments somewhere in the McMurdo Sound area was demonstrated some years ago by the discovery of pollen-bearing siltstones of Eocene age as boulders in moraines at Minna Bluff and Black Island (Cranwell et al., 1960; McIntyre and Wilson, 1966; Wilson, 1967a). Further, the recovery of quantities of recycled early Tertiary pollen in modern Ross Sea sediments (Wilson, 1968; Kemp, 1972) led to the suggestion that submarine or subice outcrops of this age might be present in the area. The penetration of this sequence, if complete enough, should have provided a palynological reflection of vegetation change under dramatically deteriorating climatic conditions.

Site 270 did not, however, provide such an ideal sequence. The preglacial sedimentary sequence at the site is thin, being confined to a meter-thick quartz sand unit, succeeded by a further meter of glauconitic sandstone. Overlying these is the 364-meter-thick pebbly, silty claystone, of glacial marine origin. The probable late Oligocene age of the preglacial units, and of the lowest glacial marine subunit, has been discussed above. The change from nonglacial depositional conditions to one in which processes of glacial marine sedimentation prevailed appears to have occurred within a relatively short interval.

Samples of preglacial and glacial marine units were examined for spores and pollen. Sample intervals are shown in Figure 2. Both preglacial units were barren, due probably to current sorting (see grain-size analyses of Barrett, this volume, fig. 5). Samples from Unit 2, the oldest glacial marine unit, do, however, contain wellpreserved spores and pollen in varying abundance. Pollen content is highest in the basal lithologic subunit (Subunit 2J), which is a laminated burrowed siltstone with rare limestones. In addition to spores and pollen, the lowest part of this subunit yielded large quantities of degraded plant debris, of tissue, and cuticle fragments, 


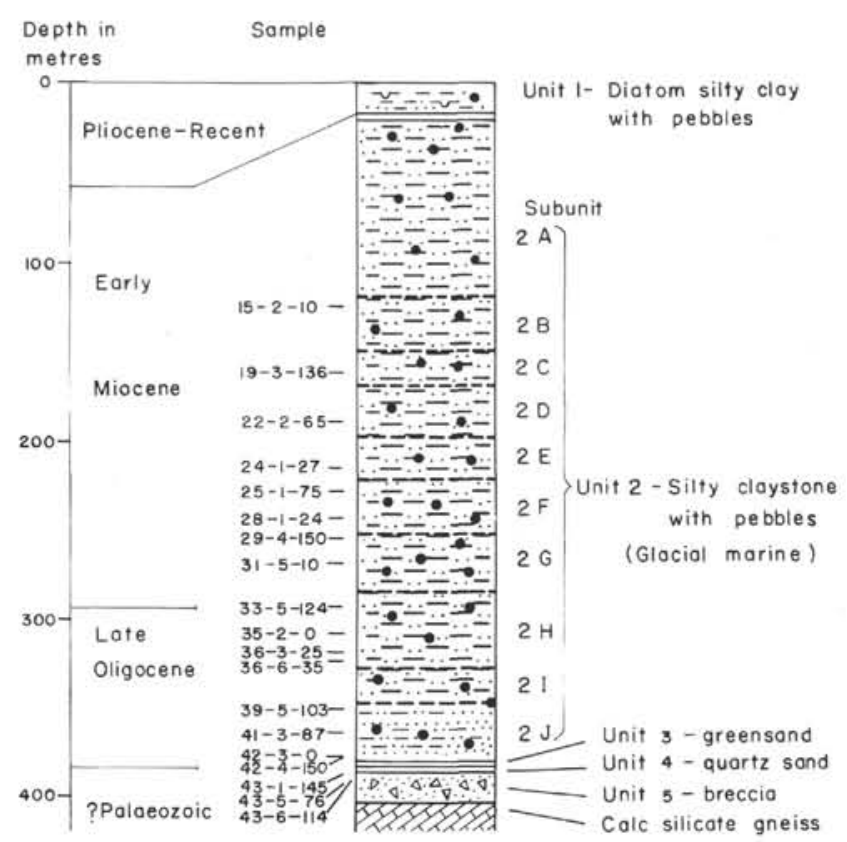

Figure 2. Lithologic sequence at Site 270. Palynological sample horizons shown on left side of column.

suggesting deposition relatively close to shore. The ratio of spores and pollen to marine microplankton decreases above Subunit 2J, but there are relatively high proportions of pollen in Subunits $2 \mathrm{~F}$ and $2 \mathrm{~B}$.

It is not certain whether the spores and pollen recovered from Unit 2 derive from a parent vegetation which flourished during deposition of the unit, or whether they have been recycled from older deposits by glacial processes. The fact that most of the spore and pollen species are known to have relatively long stratigraphic ranges where they occur in Australia and New Zealand makes it impossible to use such stratigraphic ranges as an index of reworking. However, it should be noted that in the assemblages from Subunit 2J, no spore forms which are obviously recycled from older deposits were observed; there are none which derive from Paleozoic and Mesozoic sequences in the Transantarctic Mountains. Nor are there any of the dinoflagellate cyst species which are present in great abundance (50\%-90\%) in the Minna Bluff and Black Island erratics. The absence of these seems to be a strong point in suggesting that the pollen assemblages of Subunit 2J, at least, do not derive from recycling. The more sparse assemblages of Subunits $2 \mathrm{~F}$ and $2 \mathrm{~B}$ do contain Eocene-early Oligocene dinoflagellate cysts (in Cores 24, 25, 29; see Table 1), so the likelihood of recycling in these units is stronger.

Interpretation of the sedimentary record throughout much of the glacial sequence in the Ross Sea has been made in terms of an alpine, temperate-type of glacial environment (Barrett, this volume), and foraminiferal evidence may also be cited to support the idea that the initial advances of the ice were not extensive. The persistence of some form of vegetational cover into the late Oligocene, then, remains a possibility on general geological grounds.

Palynological assemblages recovered from the glacial marine sequence are much less diverse than those of comparable age in Australia and New Zealand. The Ross Sea assemblages are dominated by Nothofagidites, with fossil forms similar to pollen of the extant fusca group predominating, but present in only slightly greater proportions than those of the brassi group. Proteaceous pollen are next in abundance, and it is here that the contrast in diversity with Australian early Tertiary assemblages is most evident. At Site 270, proteaceous pollen are chiefly of the small, smoothwalled $P$. minimus type; forms with elaborate reticu-late exine patterns occur only rarely.

Small myrtaceous pollen are also a rare component of the angiosperm spectrum, as are tricolpate forms, including one close to the New Zealand species Tricolpites matauraensis. Gymnosperm pollen are dominated by podocarpaceous types, among which the longranging Microcachryidites antarcticus and Podosporites microsaccatus are most common. The species Lygistepollenites florinii, which has a mid Paleocene-Miocene range in southeast Australia (Stover and Partridge, 1973) occurs rarely. Cycadophyte pollens were not observed. Fern spores are a rare component and most are of the smooth-walled Cyathidites type; monolete types are present, but again rare, and include some polypodiaceous forms.

The composition of the Unit 2 assemblage is almost identical with that described from the Black Island erratics by McIntyre and Wilson (1966). Those assemblages are probably of late Eocene age, on dinoflagellate evidence. McIntyre and Wilson interpreted the microflora from the McMurdo erratics as indicative of a flora growing under cool-temperate conditions, which, they argued, were considerably cooler than those of contemporary New Zealand. They noted, in this respect, the absence of pollen types which are considered to be indications of Eocene warmth in New Zealand.

The assemblages from the late Oligocene at Site 270, assuming that they are in situ, must be interpreted as reflecting an essentially similar parent vegetation to that of the Eocene erratics. It may be that the basic floristic composition of this vegetation remained virtually unchanged under increasingly adverse climatic conditions. Elements of it may have assumed morphologic and physiologic adaptations to climatic severity, such as dwarfism and increased periods of dormancy. It seems likely that the late Eocene vegetation would have been transformed into a tundra-like cover without appreciable addition of new groups by migration, which would have been extremely difficult owing to the effective isolation of Antarctica by the Oligocene. There is no evidence in the pollen record of taxa which form a significant part of the modern subantarctic vegetation; there is no record of pollen of Gramineae, Cyperaceae, Umbelliferae, or Compositae-groups which are strongly represented today on subantarctic islands. Conceivably, the isolation of the main Antarctic landmass (apart from the Antarctic peninsula) prevented these families from ever reaching the major part of the continent. The last vegetational stage may have consisted of dwarf shrubs of Nothofagus, Podocarpaceae, and Proteaceae as major elements. Perhaps surprisingly, there is no record either of abundant bryophytes, although Sphagnum type spores occur rarely; 
TABLE 1

Distribution of Microplankton, Spores, and Pollen in Productive Samples From Sites 270 and 274

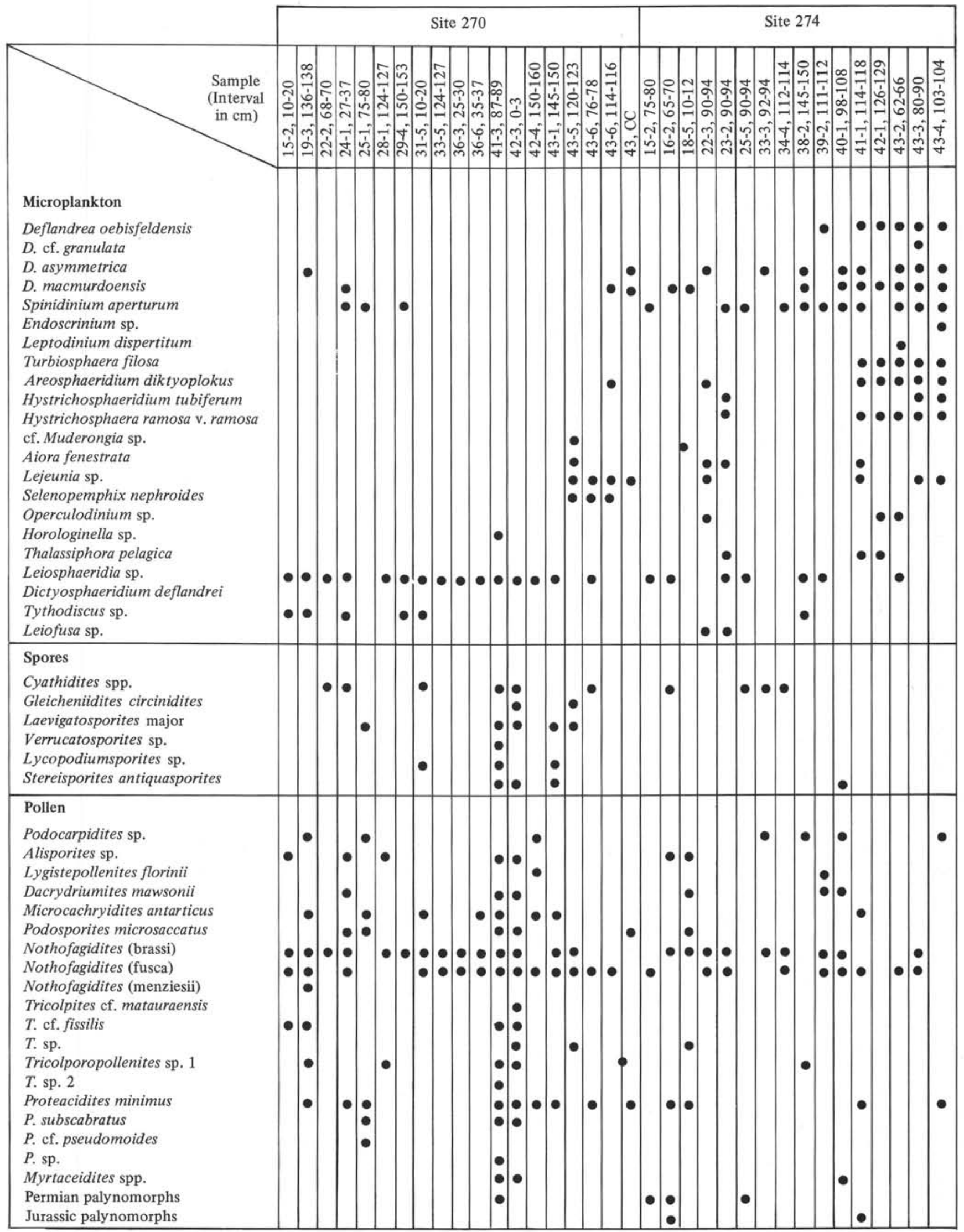


nothing is known in the palynological record to suggest a vegetational phase dominated by a moss flora. This lack may only reflect the present inadequacies of the pollen record.

In summary, assessment of available data suggests that vegetation may have persisted in the Ross Sea region until the late Oligocene. The composition of such vegetational cover appears to be floristically similar to that of the late Eocene, as this is evidenced from the McMurdo erratics. The pollen spectrum, insofar as this reflects the parent vegetation, suggests a shrub or tree cover of low diversity, with nothofagus and Podocarpaceae dominant, and Proteaceae and Myrtaceae among the minor elements. It is unfortunate that sites off the eastern margin of the continent, i.e., Sites 268 and 269 , failed to yield sufficient pollen to substantiate a similar picture in that region, although sparse assemblages in probable late Oligocene sequences at Site 268 (again with Nothofagidites, Podocarpidites, and Proteaceae) do not conflict with this suggested vegetation history.

\section{SYSTEMATIC NOTES-DINOFLAGELLATES}

\section{Class DINOPHYCEAE Pascher}

Cyst-Family DeFLANDREACEAE Eisenack

emend. Sarjeant and Downie 1966

Genus DEFLANDREA Eisenack

emend. Williams and Downie 1966

\section{Deflandrea oebisfeldensis Alberti, sensu Cookson and Cranwell 1967 (Plate 1, Figures 1-6)}

Deflandrea oebisfeldensis Alberti, Cookson and Cranwell 1967, p. 205, pl. 1, fig. 1, 2.

Remarks: Precise identification of large specimens of Deflandrea is hindered by poor preservation, especially by breakage of anterior and posterior test regions. Considerable morphologic variation is also evident and gradational for some features. All specimens are broadly fusiform, with epitract $1 \frac{1}{2}$ to $12 / 3$ as large as hypotract. Apical horn tapers generally to a blunt tip, from rounded shoulders developed above the capsule. Antapical horns equal in size, bluntly conical. Test wall layers are closely adpressed in the capsule region. Cingulum distinct, slightly depressed, frequently bordered by small granules. Sulcus discernible, but margins clear only on hypotract. Epiphragm surface usually with scattered grana, rarely small spines; some specimens (see Plate 1, Figure 1) show a concentration of these in a tapering panel on the epitract. Archeopyle intercalary. Endophragm robust, spongose exteriorly, 3.0-5.0/ $\mu$ thick.

Comparison: The observed specimens are closest to those described by Cookson and Cranwell from the Lena Dura Formation of southern Chile, and referred by those authors to $D$. oebisfeldensis Eisenack. Both the Lena Dura and the Site 274 specimens are, however, probably distinct from $D$. oebisfeldensis, described from the early Eocene of West Germany, in that they invariably show close adpression of wall layers in the girdle region. The cingulum and sulcus are more clearly developed in the southern forms. The close adpression of the wall layers also distinguishes the form from $D$. phosphoritica (including the subspecies australis Cookson and Eisenack), as does the shape of apical and antapical horns. It is not strictly conspecific with other southern forms, differing from $D$. fuegiensis Menendez in being larger, with a thicker endophragm; from $D$. distincta Wilson in lacking conspicuous wall folds, and from $D$. antarctica Wilson in lacking an apical papilla, and in having more conical antapical horns. The range of variation observed may, however, include representatives of this species.

Dimensions: Test length $120-180 \mu$; breadth $70-92 \mu$; capsule length 66-94 $\mu$; endophragm thickness $3-5 \mu$.

Occurrence in Leg 28 sediments: Site 274, unit 5, common in all core samples.
Deflandrea sp. cf. D. granulata Menendez 1965

(Plate 1, Figures 7, 8)

Remarks: These forms are distinguished from those referred to $D$. oebisfeldensis in having a thin endophragm and a granulate epiphragm. They are close to those figured by Archangelsky and Fasola (1971, pl. 1, fig. 1-4) from the Loreto and Rio Turbio formations of Patagonia.

Dimensions: Test length $134,136 \mu$; breadth $80,72 \mu$; capsule length $98,83 \mu$; endophragm approximately $2 \mu$ thick.

Occurrence in Leg 28 sediments: Sites 274, Unit 5, rare.

\section{Deflandrea asymmetrica Wilson 1967}

(Plate 1, Figures 9, 10)

Remarks: This form was originally described from Minna Bluff and Black Island, McMurdo Sound, and has since been recorded only from the Rio Turbio Formation of southern Argentina (Archangelsky, 1969), where it is most common in the lower (possibly mid Eocene) part of that unit. Its full range is incompletely known.

Occurrence in Leg 28 sediments: Site 274 , Unit 5, rare. Occurs also in the greensand (Unit 3) at Site 270, again as a rare element; also in Subunit $2 \mathrm{C}$ of that site, possibly as a recycled element.

\section{Deflandrea macmurdoensis Wilson 1967}

(Plate 2, Figures 1-5)

Remarks: D. macmurdoensis has hitherto been described from only two localities; from McMurdo Sound erratics (whence it was originally described), and from southern South America. There it is common in the upper Rio Turbio Formation of Argentina and occurs in the lower part of the Loreto Formation of Chile. The range of the species appears, therefore, to be mid or late Eocene to Oligocene.

Occurrence in Leg 28 sediments: Site 270-Unit 3 (greensand), rare; Subunit 2E (possibly recycled). Site 274-Unit 5, common in all samples; Unit 3, Core 16 (possibly recycled).

\section{Cyst-Family PAREODINIACEAE Gocht emend. Sarjeant and Downie 1966 \\ Genus SPINIDINIUM Cookson and Eisenack 1962 \\ Spinidinium aperturum Wilson 1967 \\ (Plate 2, Figures 6-8)}

Remarks: All specimens observed were identified as $S$. aperturum on the basis of their relatively small size. In their general roundness, however, some are close to the larger form $S$. rotundum Wilson. $S$. aperturum was previously known only from the McMurdo erratics; $S$. rotundum, which possibly overlaps $S$. aperturum, occurs in Eocene to Oligocene sediments in South America (Archangelsky and Fasola, 1971).

Dimensions: Length $38-52 \mu$; breadth $32-44 \mu$.

Occurrence in Leg 28 sediments: Site 270 -Subunits $2 \mathrm{E}, 2 \mathrm{~F}, 2 \mathrm{~J}$ (reworked?), very rare. Site 274-Unit 5, present in all cores, but never common; Unit 4, Cores 24,25 , rare. Unit 3, Core 15 (reworked?), rare.

\section{Cyst-Family ENDOSCRINIACEAE Vozzhenikova emend. Sarjeant and Downie 1966 \\ Genus ENDOSCRINIUM Klement emend. Vozzhenikova 1967 \\ Endoscrinium sp. \\ (Plate 2, Figures 12, 13)}

Remarks: This cavate, tabulate form is referred to Endoscrinium rather than to Hexagonifera Cookson and Eisenack because of the precingular position of the archeopyle. The form is always clearly cavate, with the capsule eccentric, so that the greatest cavity development is posterior. The cingulum is strongly helicoid, bordered by sutural crests; tabulation is not clear, but a formula of $1^{\prime}, 5-6^{\prime \prime}, 6 \mathrm{c}, 4^{\prime \prime \prime}$, $\mathrm{I}^{\prime \prime \prime \prime}$ is suggested.

Dimen sions: Length $68-79 \mu$; breadth $52-72 \mu$; capsule length $52-62 \mu$ (4 specimens).

Occurrence in Leg 28 sediments: Site 274 , Unit 5, Cores 42, 43, very rare. 
Cyst-Family GONYAULACYSTACEAE Sarjeant and Downie 1966

\section{Genus LEPTODINIUM Klement 1960}

Leptodinium dispertitum Cookson 1965

(Plate 2, Figures 9-11)

Remarks: The specimens recovered conform closely to $L$. dispertitum in showing a division of the vertical field into three plate areas; the exine of some is, however, thicker than that of the type specimen. $L$. dispertitum was originally described from the late Eocene Brown's Creek Clays of Victoria; recently Benedek (1972) recorded it from the late Oligocene of Germany.

Occurrence in Leg 28 sediments: Site 274, Unit 5, Core 43, very rare.

\section{Cyst-Family HYSTRICHOSPHAERIDIACEAE Evitt emend. Sarjeant and Downie 1966}

Genus TURBIOSPHAERA Archangelsky 1968

Turbiosphaera filosa (Wilson) Archangelsky 1968

(Plate 3, Figures 1-4)

Cordosphaeridium filosum Wilson, 1967a, p. 66, fig. 2b, 31, 32, 34 .

Forma F of Evitt, Cookson and Cranwell, 1967, p. 207, pl. 3, fig. 3.

Turbiosphaera filosa (Wilson) Archangelsky, 1968, p. 408, pl. 1, fig. 1-

4.

Remarks: Specimens identified here as $T$. filosa are morphologically closest to those described from the Rio Turbio Formation of Argentina by Archangelsky (1968). They differ from those described from the McMurdo erratics by Wilson (1967a), in having processes which are diffuse and much-flared distally, rather than being concentrated into distinct fibrous aggregates. The periphragm formed by the flaring ends of the processes partially envelops the capsule. Rare specimens, however, show thin, densely corded processes (Plate 3, Figures 3, 4).

In South America, the form is most common in the upper part of the Rio Turbio Formation (mid-late Eocene, Archangelsky and Fasola, 1971).

Occurrence in Leg 28 sediments: Site 274, Unit 5 (lower part), Cores $40-43$, rare to common.

\section{Genus AREOSPHAERIDIUM Eaton 1971 \\ Areosphaeridium diktyoplokus (Klumpp) emend. Eaton 1971 \\ (Plate 3, Figures 5-8)}

Remarks: Ross Sea specimens attributed to this species do not cover the full range of morphological variation shown by European assemblages, especially in the nature of the distal terminations-in Ross Sea specimens these are ragged, rarely entire-margined. The reflected tabulation, however, conforms to that described by Eaton (1971). Most observed specimens had lost the operculum. Processes are 13-16 in number, mostly uniform, but with two or three slender elements in the cingulum region.

Eaton reviewed the distribution of the species to 1970; no new records appear to have been published since that date. Most records are from the Eocene although there remains one occurrence in the Oligocene of Germany (Maier, 1959); the early Oligocene record of Eisenack (1954) has now been classified as late Eocene (Eisenack, quoted in Cookson and Cranwell, 1967). Specimens in the Loreto Formation of Chile (Archangelsky and Fasola, 1971) occur within possible Oligocene sediments, but may be recycled. Presently, it is uncertain whether specimens from Leg 28 sediments which are independently dated as Oligocene (Site 274, Unit 4) represent a definite extension of the species range into the Oligocene, or whether they are recycled. The former explanation is preferred.

Occurrence in Leg 28 sediments: Site 270-Unit 3, Core 43, very rare. Site 274-Unit 5, Cores 40-43, rare to common; Unit 3, core 22, rare.

\section{Genus HYSTRICHOSPHAERIDIUM Deflandre 1937}

\section{Hystrichosphaeridium tubiferum (Ehrenberg) Deflandre 1937} (Plate 4, Figures 1-3)

Remarks: The specimens observed are close to those figured by Wilson (1967a) from Black Island and Minna Bluff. As the species ranges back as far as the Cenomanian, it has little stratigraphic significance.

Occurrence in Leg 28 sediments: Site 274, Unit 5, rare.
Cyst-Family HYSTRICHOSPHAERACEAE O. Wetzel emend. Evitt, emend. Sarjeant and Downie 1966

Genus HYSTRICHOSPHAERA O. Wetzel

\section{Hystrichosphaera ramosa (Ehrenberg)} var. ramosa Davey and Williams 1966

(Plate 4, Figures 4-7)

Remarks: All observed specimens fall within $H$. ramosa var. ramosa, as variation in wall structure appears to be quite gradational, and the size range is very narrow (46-62 $\mu$ ), suggesting a single taxonomic entity.

Distribution in Leg 28 sediments: Site 274 , Units 4 and 5, rare to very common.

\section{Cyst-Family THALASSIPHORACEAE Gocht 1969 \\ Genus THALASSIPHORA Eisenack and Gocht emend. Williams and Downie 1966 \\ Thalassiphora sp. ef. T. pelagica \\ (Eisenack) Gocht 1968 \\ (Plate 5, Figures 1-4)}

Remarks: $T$. pelagica was described originally from the early Oligocene (now regarded as late Eocene) of Germany; it has since been recorded widely from sediments ranging in age from early Eocene to Miocene (Gerlach, 1961). The specimens recovered from Leg 28 are not equated directly with $T$. pelagica, because they consistently show the presence of a fibrous "tail," formed from a dense aggregation of threads at the posterior end of the capsule, where the wall is drawn out. This feature is not observable in illustrations of European forms. Additionally, the posterior projection from the edge of the wing is larger and more fibrous in the Antarctic specimens.

Distribution in Leg 28 sediments: Site 274, Unit 5, Cores 40-43, rare; Unit 4, Core 23, rare.

\section{FAMILY UNCERTAIN \\ cf. Muderongia sp. \\ (Plate 4, Figures 12, 13)}

Comment: Assignment of tests recovered from the base of Unit 2, Site 270 , to the Cretaceous genus Muderongia is made with reservation; the species is characterized by elongate apical and antapical horns and by smaller lateral horns, but is acavate, which probably precludes reference to Muderongia. Possibly the creation of a new genus is necessary, but the material is too poorly preserved to justify this. The test is frequently intensely folded, so the form of all four horns is difficult to observe. The antapical (?) horn is divided into two projections of equal length near its posterior extremity. No shell opening was observed.

Dimensions: Length $112-129 \mu$; breadth $60-69 \mu$ (4 specimens).

Occurrence: Site 270, Subunit 2J, Core 43.

\section{Genus AIORA Cookson and Eisenack 1960 \\ Aiora fenestrata (Deflandre and Cookson) \\ Cookson and Eisenack 1960}

(Plate 4, Figures 8, 9)

Remarks: Specimens recovered from Leg 28 appear to be conspecific with $A$. (al Cannosphaeropsis) fenestrata, which was typified from the Molecap Greensand of Western Australia, of probable Senonian age (Deflandre and Cookson, 1955). A. fenestrata appears to be southern in its distribution, and has been recorded from the Rio Turbio Formation of Argentina (Archangelsky, 1968), from Tierra del Fuego (Pothe de Baldis, 1966), and from McMurdo erratics (Wilson, 1967a), all of which are probable Eocene records. These are stratigraphically disjunct from Australian records, as the form has not been recovered there from strata younger than Late Cretaceous. In this study, well-preserved specimens of this delicate form occur in the upper part of the Oligo-cene sequence at Site 274 , where they do not appear to be recycled.

Distribution in Leg 28 sediments: Site 273, Unit 5, rare; Unit 4 (upper part only), rare. Site 270, Subunit 2J, rare. 
Genus LEJEUNIA Gerlach 1961 emend. Kjellström 1972

Lejeunia sp.

(Plate 4, Figures 10, 11)

Remarks: Specimens of this distinctive form fall into Lejeunia, as this genus was emended by Kjellström (1972). About half of the observed Antarctic specimens show a large precingular archeopyle. Further distinctive features are the possession of solid tips on apical and antapical projections and the brown nonstaining nature of the test wall. Lejeunia fallax Morgenroth (1966, pl. 1, fig. 6, 7) from the midOligocene of Germany bears some resemblance, but lacks the solid horn tips and is smaller. There was no archeopyle recorded in that species. Lejeunia sp. of Drugg (1967, pl. 1, fig. 16), from the late Cretaceous of California, is closely similar to the Antarctic species.

Dimensions: Length $83-106 \mu$; breadth $76-86 \mu$; archeopyle $37 \mu$ diameter.

Occurrence in Leg 28 sediments: Site 274, Unit 5, rare; Site 270, Subunit $2 \mathrm{~J}$, rare to common; Unit 3, rare.

\section{Genus SELENOPEMPHIX Benedek 1972}

\section{Selenopemphix nephroides Benedek 1972}

(Plate 5, Figures 7-9)

Remarks: This occurrence appears to be the first record of $S$. nephroides outside Germany, where it was described from mid to late Oligocene strata (Benedek, 1972, pl. 11, fig. 13; pl. 16, fig. 1-4). The only detectable difference between the Antarctic and the German forms is the lack in the former of a distinct opening in the apical region; in some specimens (e.g., pl. 5, fig. 8) this is, however, weakly suggested. The brown, nonstaining finely granulate wall is identical in both records. In Leg 28 sediments, $S$. nephroides is common in the distinctive, probably shallow-water facies of Subunit 2J at Site 270.

Dimensions: Length $64-104 \mu$; width $66-90 \mu$.

Occurrence in Leg 28 sediments: Site 270, Subunit $2 \mathrm{~J}$ (Core 43 only), common; Unit 3, rare.

\section{Genus OPERCULODINIUM Wall 1967}

\section{Operculodinium sp.}

(Plate 5, Figures 5, 6)

Remarks: This form bears some resemblance to $O$. centrocarpum (Deflandre and Cookson), described originally from the mid-Miocene of Victoria, but the processes are less dense and the bifurcate terminations are coarser in the Antarctic species. Forms similar to this were identified by Davey (1969) as $O$. centrocarpum from late Cretaceous sediments of northern Natal. rare.

Occurrence in Leg 28 sediments: Site 274, Unit 5, rare; Unit 4, very

Genus HOROLOGINELLA Cookson and Eisenack 1962

Horologinella sp.
(Plate 6, Figure 4)

Remarks: Two specimens only of this form were observed; it does not resemble any previously described species.

Occurrence: Site 270, Subunit 2J, Core 41.

\section{Group ACRITARCHA Evitt 1963}

Subgroup SPHAEROMORPHITAE Evitt 1963

Genus LEIOSPHAERIDIA Eisenack 1958

\section{Leiosphaeridia sp.}

(Plate 6, Figures 1-3)

Remarks: Leiospheres encountered in Leg 28 sediments fall within a narrow size range $(18-30 \mu)$ and show little morphological variation, being characterized by a smooth, apparently structureless hyaline wall. There is no evidence of apertural mechanisms; the splitting frequently observed is possibly a preservational artifact. Leiospheres occur in swarm proportions (probably over 5000 per gram of sediment, on a very rough estimate) in all but the lowest parts of the glacial marine sequence at Site 270 (i.e., Subunits 2C, 2F, 2E, 2G, and upper 2J), in the upper part of Unit 4 at Site 274, and at the base of Unit 3 at Site 268. Ecological implications are presently obscure, but there is some suggestion that such swarms are confined to deep-water regimes.

\section{SUBGROUP UNCERTAIN}

Genus DICTYOSPHAERIDIUM W. Wetzel 1952

\section{cf. Dictyosphaeridium deflandrei W. Wetzel 1952}

(Plate 6, Figures 5, 6)

Remarks: Reference to $D$. deflandrei is very tentative, in view of the presence of apparent plate boundaries in Antarctic specimens, a feature which is not visible in the type material from the Danian of northwest Europe, nor in the specimens figured from McMurdo Sound by Wilson (1967a). The possibility remains that the form is in fact a dinoflagellate cyst; some resemblance to Cassidium fragilis (Harris) Drugg is noteworthy.

Occurrence: Site 274, Unit 5, very rare.

\section{Class CHLOROPHYCEAE}

\section{Family TASMANACEAE Sommer 1956}

Genus TYTTHODISCUS Norem 1955

\section{Tytthodiscus sp.}

(Plate 6, Figures 7-9)

Comment: Thick-walled microfossils with prominent wall canals are referred here to Tytthodiscus rather than to Crassosphaera, since most are disc-shaped, although the observed shape possibly results from splitting of an original near-spherical form and is further emphasized by compression. All specimens observed are distinguished by thick $(5-10 \mu)$ walls, with radially aligned groups of two to three canals which emerge from domed exterior projections. The species bears some resemblance to that referred to $T$. cf. suevicus Eisenack by Benedek, from the Oligocene of Germany, but the Antarctic specimens are more thick walled.

Dimensions: $72-116 \mu$ diameter.

Occurrence in Leg 28 sediments: Site 270, Subunits 2C, 2E, 2G (very rare); Site 274, Unit 5 (upper part only), rare.

\section{POLLEN (TAXONOMIC NOTES ON SELECTED FORMS)}

\section{Genus NOTHOFAGIDITES (Erdtman) Potonié 1960 \\ Nothofagidites spp. \\ (Plate 6, Figures 16-21)}

Remarks: Pollen of the type produced by the extant genus Nothofagus is the most conspicuous element of the Antarctic pollen spectrum. All three major morphological types ( $N$. fusca, $N$. brassi, $N$. menziesii) are present, with $N$. fusca types most abundant, and $N$. menziesii extremely rare. In Plate 6, all except Figure 21 represent the brassi type, Figure 21 is a fusca type. Because of the acknowledged difficulty of separating extant species on the basis of pollen morphology, the fossil species erected by Cookson (1959) and Couper $(1953,1960)$ have not been consistently identified in this study. Plate 6 includes forms which are morphologically close to the type specimens of $N$. vausteenisi Cookson, $N$. hetera Cookson, $N$. matauraensis Couper and N. cincta Cookson (see Plate explanation).

Occurrence in Leg 28 sediments: Recovered from all productive samples at Site 270, rare at Site 274, 268, 269.

\section{Genus TRICOLPITES Cookson ex Couper 1953 \\ Tricolpites sp. cf. T. fissilis Couper 1960 \\ (Plate 7, Figures 5, 6)}

Remarks: This form, which shows considerable variation in colpus length from forms with short colpi to those in which the colpi nearly meet in polar regions, is slightly smaller, and usually has a thinner exine than $T$. fissilis, which Couper (1960) recorded from the New Zealand late Cretaceous.

Occurrence in Leg 28 sediments: Site 270, Subunit 2J, rare.

Tricolpites spp.

(Plate 6, Figures 22, 23)

Remarks: Tricolpate pollens with reticulate exine patterns are rare in the Antarctic material. Those specimens with a finer reticulum are close to T. matauraensis Couper, which is known from New Zealand Eocene to Miocene strata.

Occurrence in Leg 28 sediments: Site 270, Subunit $2 \mathrm{~J}$, rare. Occurs sporadically in Subunits $2 \mathrm{~B}$ and $2 \mathrm{~F}$ at this site. 
Genus TRIPOROPOLLENITES Pflug and Thomson 1953

Triporopollenites sp. 1

(Plate 7, Figure 10)

Remarks: This form bears some resemblance to $T$. chnosus Partridge, from the early Eocene through Miocene of the Gippsland Basin (Stover and Partridge 1973), but has a proportionately much thinner exine. T. subalveolatus Couper from the New Zealand late Cretaceous has a more strongly sculptured exine.

Occurrence in Leg 28 sediments: Site 270, Subunit 2J, rare.

Triporopollenites sp. 2

(Plate 7, Figures 11, 12)

Remarks: This form superficially resembles Anacolosidites, but is triporate, rather than hexaporate. The grains are usually distorted, strongly folded, the exine $1 \mu$ thick overall, but thickened distinctly about the apertures, and granulate in polar areas.

Dimensions: $44-52 \mu$.

Occurrence in Leg 28 sediments: Site 270, Subunit 2J, rare.

\section{Genus PROTEACIDITES Cookson ex Couper 1953}

Remarks: Grains of the type produced by extant Proteaceae are common in most productive samples. The lack of diversity in the Antarctic forms is conspicuous, compared to early Tertiary assemblages from New Zealand, and, more strikingly, Australia. Small forms with smooth or faintly scabrate exines are the most common element-the large reticulate and granulate types which characterize the Australasian assemblages are conspicuously absent.

The small forms are assigned here to two form species, separated on the basis of the presence or absence of exine thickening about the ora; there is, however, a considerable overlap between them.

\section{Proteacidites minimus Couper}

(Plate 7, Figures 1, 2)

Remarks: Straight-sided, smooth to scabrate forms which lack exinal thickening about the aperture are referred to $P$. minimus, which is a long-ranging species, described originally from the Oligocene to Pleistocene of New Zealand.

Occurrence in Leg 28 sediments: Site 270, Subunits 2J, 2F, 2B, rare; Site 268, Unit 3, Cores 18, 20, rare; Site 274, Unit 5, very rare.

\section{Proteacidites subscabratus Couper}

$$
\text { (Plate 7, Figures 3, 4) }
$$

Remarks: Smooth to scabrate forms with apertural exine thickening are referred to $P$. subscabratus, which occurs in New Zealand and Australian Paleogene sediments.

Occurrence in Leg 28 sediments: As for $P$. minimus.

\section{Proteacidites sp. cf. P. pseudomoides Stover}

(Plate 7, Figures 8, 9)

Remarks: These rare small forms are recorded as being the only reticulate types observed. Preservation is too poor to refer them confidently to $P$. pseudomoides, which occurs in the Eocene to Oligocene of the Gippsland Basin.

Occurrence in Leg 28 sediments: Site 270 , Subunit 2 F, very rare.

\section{Proteacidites sp.}

(Plate 7, Figure 7)

Remarks: This straight-sided, coarsely granulate form does not closely resemble any described Australasian species. The exine pattern, however, is suggestive of that in P. clintonensis Harris from the Eocene of South Australia (which Stover and Partridge regard as synonymous with $P$. rectomarginis Cookson), but the Antarctic form is much coarser.

Occurrence: Site 270 , Subunit 2 J, extremely rare.

\section{Genus MYRTACEIDITES Cookson and Pike emend. Potonié 1960}

Mytaceidites spp.

(Plate 6, Figures 24, 25)

Remarks: Mytaceous pollen observed is mostly small, akin to $M$. eugeniioides Cookson and Pike (Fig. 24) but grains of a larger, more robust type occur as a rare element (Fig. 25).

Occurrence in Leg 28 sediments: Site 270, Subunit 2J, rare.

\section{ACKNOWLEDGMENTS}

Participation in the Leg 28 cruise was made possible through a grant from the U.S. National Science Foundation. Work on the core samples was carried out at the Bureau of Mineral Resources, Canberra. Publication of results is made with the permission of the Director.

I am indebted to Graeme J. Wilson, New Zealand Geological Survey, Lower Hutt, for helpful correspondence and for critically reading a first draft of the manuscript.

\section{REFERENCES}

Archangelsky, S., 1968. Sobre el paleomicroplancton del Terciario Inferior de Rio Turbio, Provincia de Santa Cruz: Ameghiniana, v. 5, p. 406-416. 1969. Estudio del paleomicroplancton de la Formacion Rio Turbio (Eoceno), Provincia de Santa Cruz: Ameghiniana, v. 6, p. 181-217.

Archangelsky, S. and Fasola, A., 1971. Algunos elementos del paleomicroplancton del Tertiario inferior de Patagonia (Argentina y Chile): Rev. Mus. la Plata, Sec., Paleontol., v. 6, p. $1-18$.

Benedek, P. N., 1972. Phytoplankton aus dem mittel-und oberoligozän von Tonisberg (Niederrheingebiet). Palaeontographica B, v. 137, p. 1-84.

Cookson, I. C., 1959. Fossil pollen grains of Nothofagus from Australia: Roy. Soc. Victoria Proc., v. 71, p. 25-30.

1965a. Cretaceous and Tertiary microplankton from southeastern Australia: Roy. Soc. Victoria Proc., v. 78 , p. $85-93$

1965b. Microplankton from the Brown's Creek Clays, S.W. Victoria: Roy. Soc. Victoria Proc., v. 79, p. 119-131.

Cookson, I. C. and Cranwell, L. M., 1967. Lower Tertiary microplankton sp. spores and pollen grains from southernmost Chile: Micropaleontology, v. 13, p. 204-216.

Couper, R. A., 1953. Upper Mesozoic and Cainozoic spores and pollen grains from New Zealand: Paleontological Bull. Wellington, v. 22, p. 1-77.

1960. New Zealand Mesozoic and Cainozoic plant microfossils: Paleontological Bull. Wellington, v. 32, p. 1-87.

Cranwell, L. M., 1964. Hystrichospheres as an aid to Antarctic dating with special reference to the recovery of Cordosphaeridium in erratics at McMurdo Sound: Grana Palynolog., v. 5, p. 397-405.

Cranwell, L. M., Harrington, H. J., and Speden, I. G., 1960. Lower Tertiary microfossils from McMurdo Sound, Antarctica: Nature, v. 186 , p. $700-702$.

Davey, R. J., 1969. Some dinoflagellate cysts from the Upper Cretaceous of northern Natal, South Africa: Palaeontol. Africana, v. 12, p. 1-23.

Deflandre, G. and Cookson, I. C., 1955. Fossil microplankton from Australian late Mesozoic and Tertiary sediments: Australian J. Mar. Freshwater Res., v. 6, p. 242313.

Drugg, W. S., 1967. Palynology of the Upper Moreno Formation (late Cretaceous-Paleocene) Escarpado Canyon, California: Paleontographica B, v. 120, p. 1-71.

Eaton, G. L., 1971. A morphogenetic series of dinoflagellate cysts from the Bracklesham Beds of the Isle of Wight, Hampshire, England: Plankt. Conf., Rome 1970 Proc., Farinacci, A. (Ed.), Roma (Tecnoscienza), v. 1, p. 355-379.

Eisenack, A., 1954. Mikrofossilien aus Phosphoriten des samländischen Unteroligozäns und über die Einheitlichkeit der Hystrichosphaerideen: Palaeontographica A, v. 105 , p. $49-95$.

Gerlach, E., 1961. Mikrofossilien aus dem Oligozăn und Miozän Nordwestdeutschlands, unter besonderer Berück- 
sichtigung der Hystrichosphaeren und Dinoflagellaten: N. Jb. Geol. Palaont. Abhande, v. 112, p. 143-228.

Gocht, H., 1969. Formengemeinschaften alttertiären mikroplanktons aus bohrproben des erdölfeldes Meckelfeld bei Hamburg: Paleontographica B, v. 126, p. 1-100.

Habib, D., 1972. Dinoflagellate stratigraphy Leg 11, Deep sea Drilling Project. In Hollister, C. D., Ewing, J. I., et al., Initial Reports of the Deep Sea Drilling Project, Volume 11: Washington (U.S. Government Printing Office), p. $367-$ 381.

Kemp, E. M., 1972. Recycled palynomorphs in continental shelf sediments from Antarctica: U.S. Antarctic J., v. 7, p. 190-191.

Kjellström, G., 1972. Archeopyle formation in the genus $\mathrm{Le}$ jeunia Gerlach, 1961 emend.: Geol. For. Forhandl., v. 94 (3), p. 467-469.

Maier, D., 1959. Planktonuntersuchungen in tertiaren und quartaren marinen sedimenten: N. Jb. Geol. Palaont. Abhande, v. 107 , p. 278-340.

McIntyre, D. J. and Wilson, G. J., 1966. Preliminary palynology of some Antarctic Tertiary erratics: New Zealand J. Bot., v. 4, p. 315-321.
Menendez, C. A., 1965. Micro-plancton fósil de sedimntos tertiarios y cretácicos del norte de Tierra del Fuego (Argentina): Ameghiniana, v. 4, p. 7-17.

Morgenroth, P., 1966. Mikrofossilien and Konkretionen des nordwesteuropäischen Untereozäns: Palaeontographica B, v. 119, p. $1-53$.

Pothe de baldis, E. D., 1966. Microplancton del Tertiario de Tierra del Fuego: Ameghiniana, v. 4, p. 218-226.

Stover, L. E. and Partridge, A. D., 1973. Tertiary and late Cretaceous spores and pollen from the Gippsland Basin, southeastern Australia: Roy. Soc. Victoria Proc., v. 85, p. $237-286$.

Wilson, G. J., 1967a. Some new species of Lower Tertiary dinoflagellates from McMurdo Sound, Antarctica: New Zealand J. Bot., v. 5, p. 57-87.

1967b. Some species of Wetzeliella Eisenack (Dinophyceae) from New Zealand Eocene and Paleocene strata: New Zealand J. Bot., v. 5, p. 469-497.

1968. On the occurrence of fossil microspores, pollen grains, and microplankton in bottom sediments of the Ross Sea, Antarctica: New Zealand J. Mar. Freshwater Res., v. 2, p. 381-389. 



\section{PLATE 1}

All magnifications $\times 500$ unless stated otherwise.

Figures 1-6 Deflandrea oebisfeldensis Alberti, sensu Cookson and Cranwell.

1. Sample 274-43-1, 100-104 cm.

2 , 3. Sample $274-43-2,62-66 \mathrm{~cm}$ : dorsal and ventral foci.

4. Ventral view of hypotheca $(\times 1200)$.

5. Sample 274-43-2, 62-66 cm.

6. Operculum $(\times 1200)$.

Figures 7, $8 \quad$ Deflandrea sp. cf. D. granulata Menendez; Sample 274-43-2, 62-66 cm: median and dorsal foci.

Figures 9, 10 Deflandrea asymmetrica Wilson.

9. Dorsal focus on operculum.

10. Median focus. Sample 274-41-1, 114-118 cm. 
Plate 1
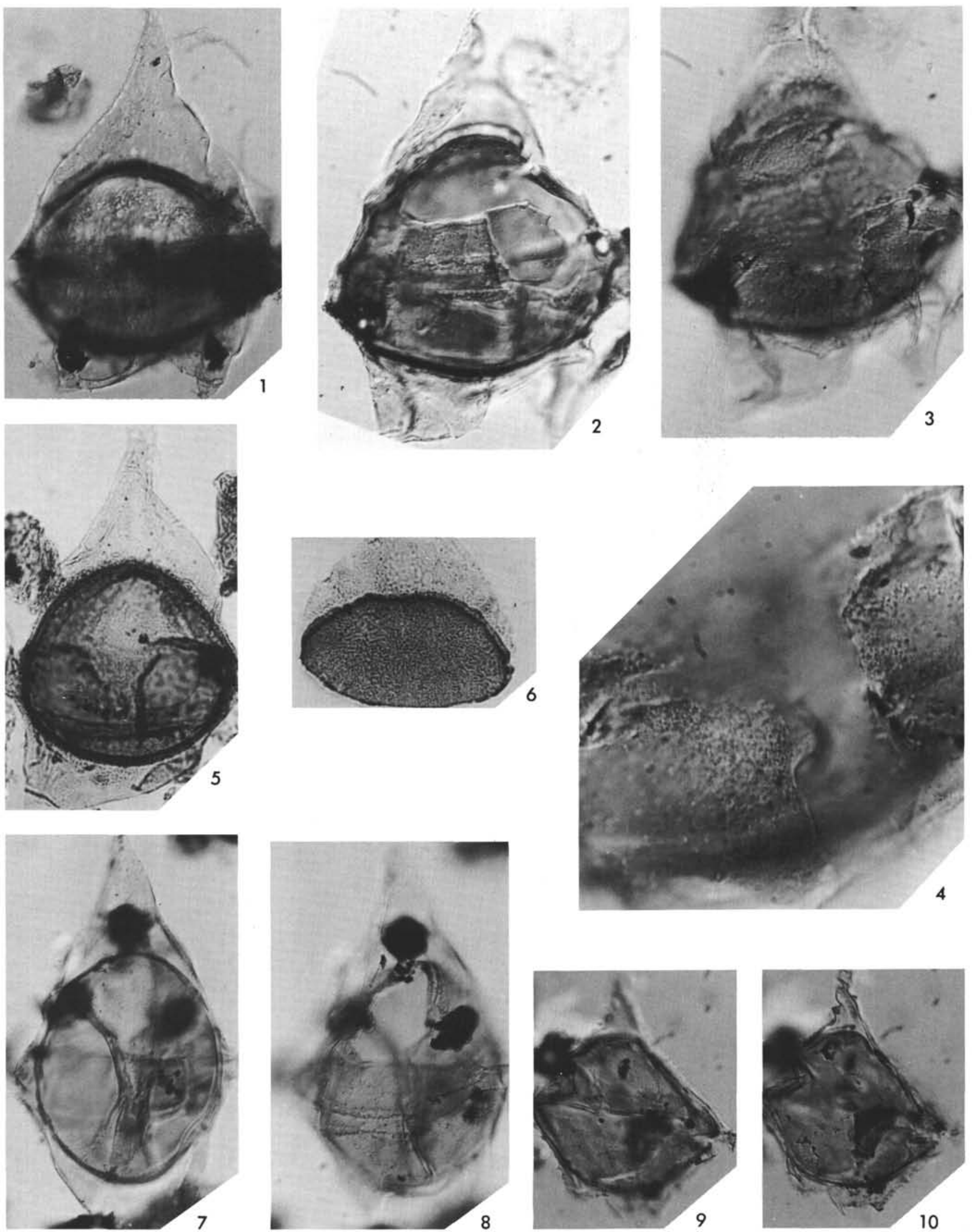


\section{PLATE 2}

All magnifications $\times 500$ unless stated otherwise.

Figures 1-5 Deflandrea macmurdoensis Wilson.

1, 2. Sample $274-43-1,100-104 \mathrm{~cm}$, dorsal and ventral foci.

3. Sample $274-43-4,103-104 \mathrm{~cm}$, dorsal focus $(\times 1200)$ showing spines delineating operculum.

4. Ventral focus $(\times 1200)$.

5. Same specimen, interference contrast.

Figures 6-8 Spinidinium aperturum Wilson; Sample 274-40-1, 98-103.

6, 8. Lateral compression.

7. Median focus.

Figures 9-11 Leptodinium dispertitum Cookson; Sample 274-432, $62-66 \mathrm{~cm}$.

9, 10. Dorsal and ventral foci.

11. Dorsal focus, interference contrast.

Figures 12, 13 Endoscrinium sp.; Sample 274-43-4, 103-104 cm. 12. Dorsal view, interference contrast.

13. Dorsal view. 
PLATE 2
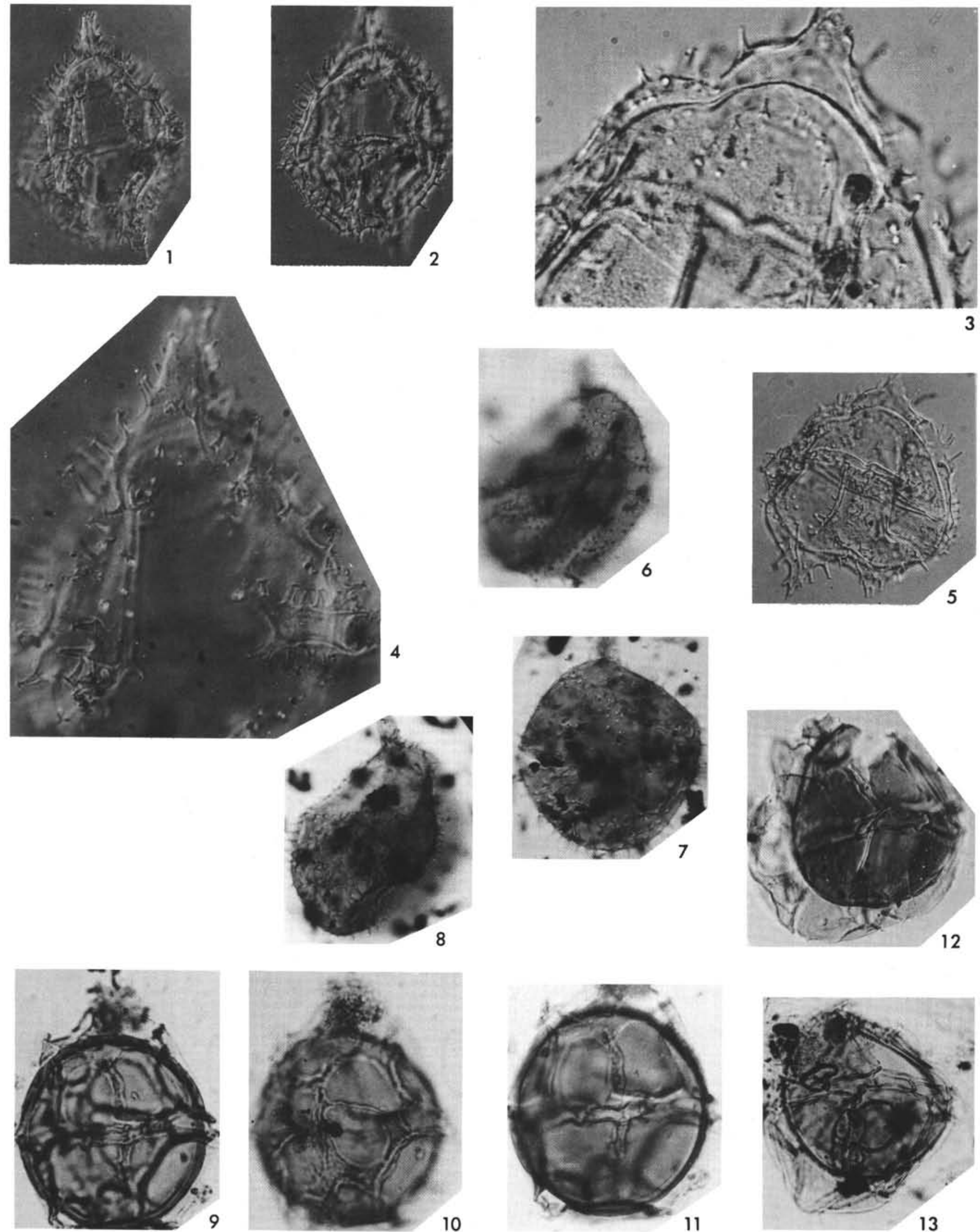


\section{PLATE 3}

All magnifications $\times 500$ unless stated otherwise.

Figures 1-4 Turbiosphaera filosa (Wilson).

1, 2. Sample 274-43-1, 100-104 cm, specimen with very diffuse processes, interference contrast.

1. Lateral view.

2. Focus on periphragm formed of distal meshlike expansion of processes $(\times 1200)$.

3. Sample 274-43-4, 103-104 cm; specimen bearing both flared and dense processes; lateral view.

4. Detail of hypotheca, showing girdle crests, dense processes and spongose surface $(\times 1200)$. Interference contrast.

Figures 5-8 Areosphaeridium diktyoplokus (Klumpp).

5 , 6. Sample $274-43-2,62-66 \mathrm{~cm}$, interference contrast.

7. Sample $274-41-1,114-118 \mathrm{~cm}$, specimen with short processes, operculum missing.

8. Sample 274-43-4, 103-104 cm, showing irregular margins of distal platforms $(\times 1200)$. 
PLATE 3
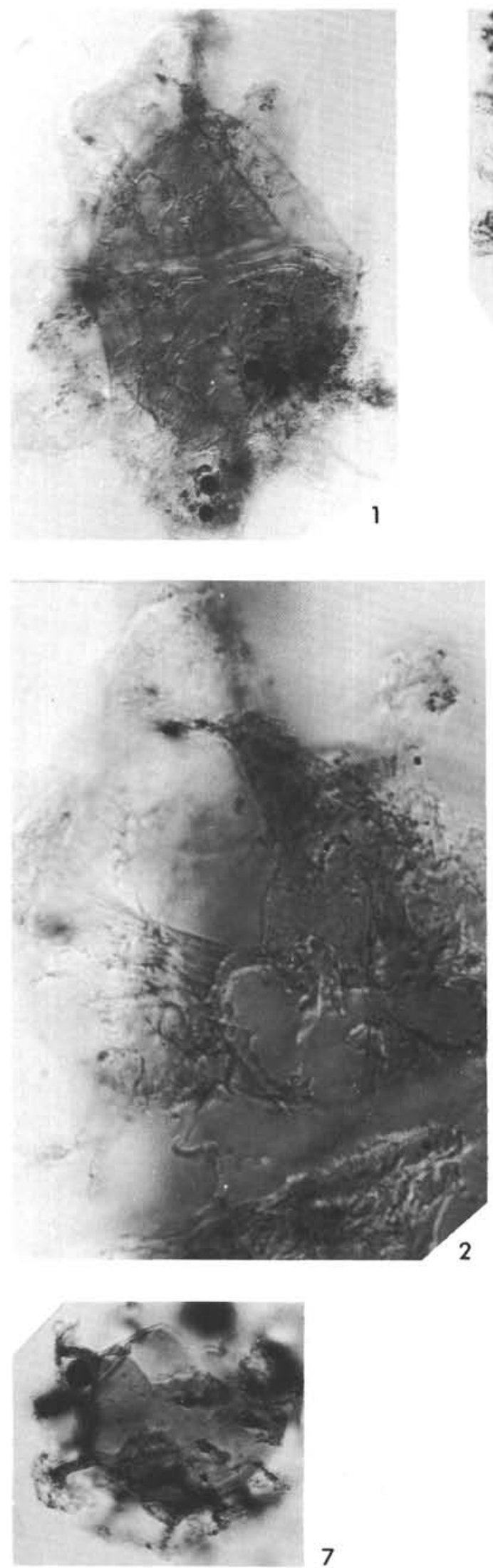
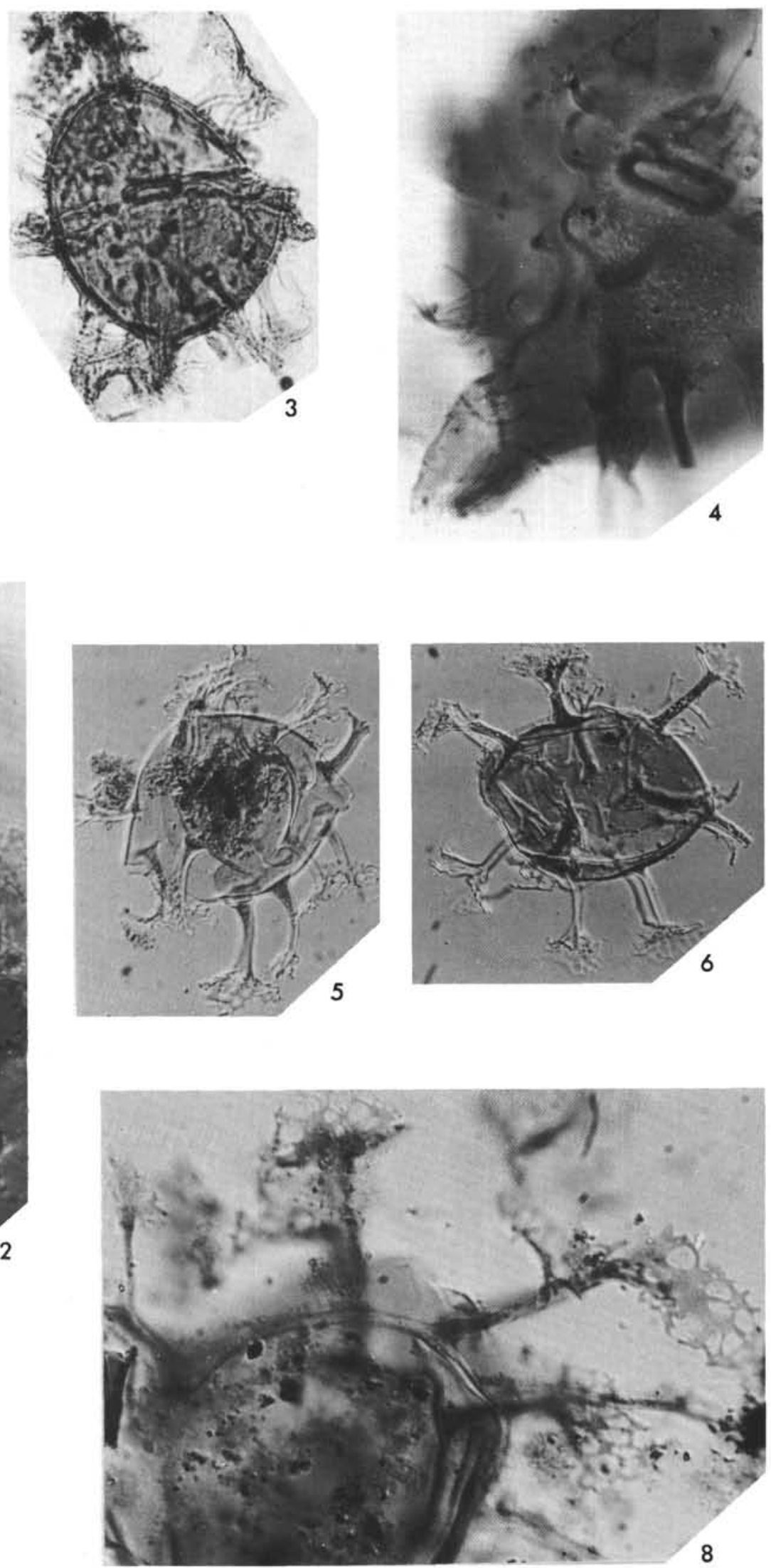


\section{PLATE 4}

All magnifications $\times 500$ unless stated otherwise.

Figures 1-3 Hystrichosphaeridium tubiferum (Ehrenberg); Sample 274-43-4, 103-104.

1, 2. Interference contrast.

3. Detail of $1(\times 1200)$, operculum missing.

Figures 4-7 Hystrichosphaera ramosa (Ehrenberg) var. ramosa Davey and Williams.

4, 5. Sample 274-43-4, 103-104 cm, dorsal and ventral foci, interference contrast.

6 . Shows apparently punctate endophragm $(\times 1200)$.

Figures 8, 9 Aiora fenestrata (Deflandre and Cookson).

8. Sample 274-43-4, 103-104 cm.

9. Sample $274-41-1,114-118 \mathrm{~cm}$.

Figures 10, 11 Lejeunia sp.

10. Sample $274-41-1,114-118 \mathrm{~cm}$, dorsal view of specimen with unusually large archeopyle.

11. Sample $270-43-5,120-123 \mathrm{~cm}$, no archeopyle visible.

Figures 12, 13 cf. Muderongia sp. Sample 270-43-5, 120-123 cm. 12. Folded specimen. 
PLATE 4
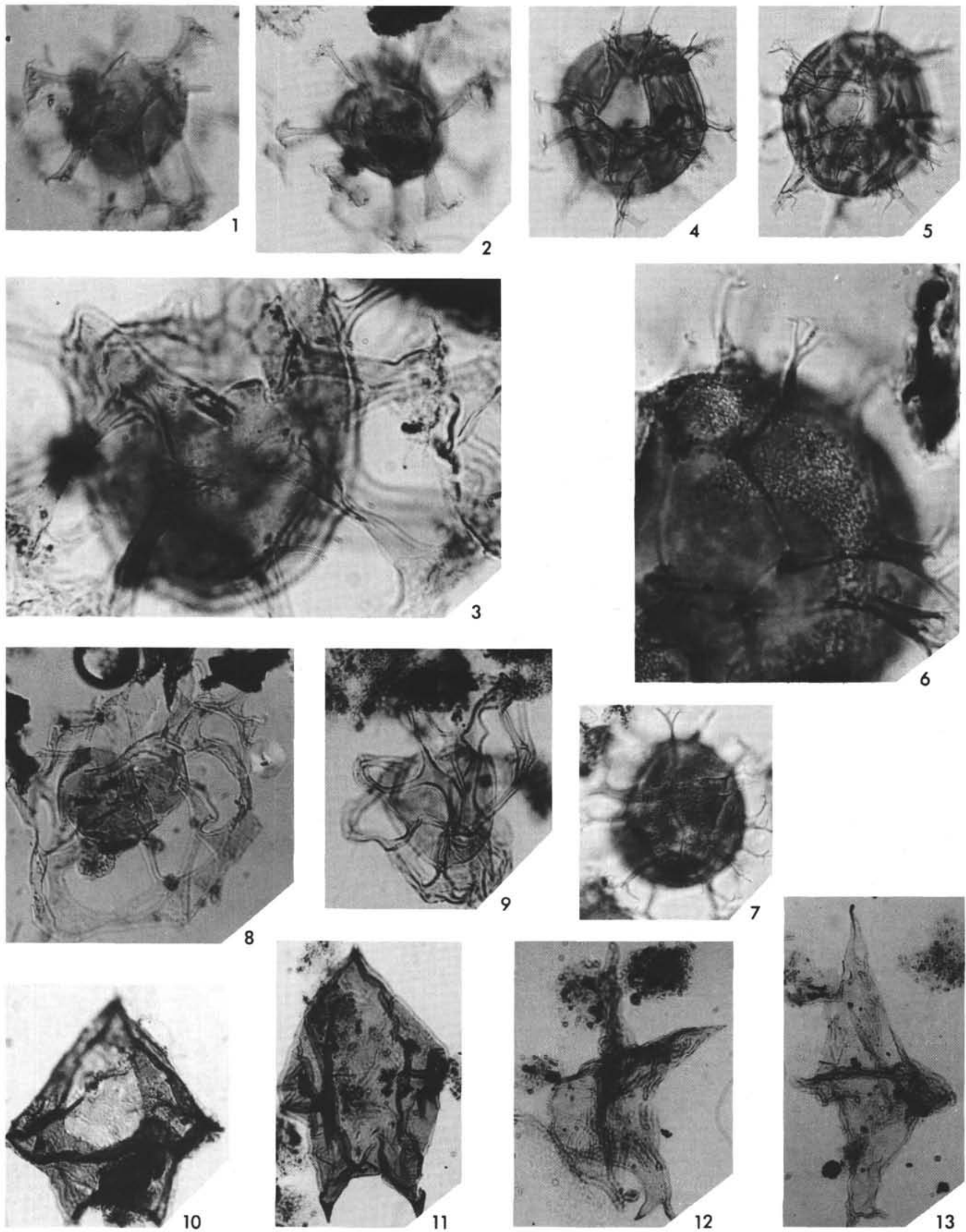


\section{PLATE 5}

All magnifications $\times 500$ unless stated otherwise.

Figures 1-4 Thalassiphora sp. cf. T. pelagica (Eisenack); Sample 274-43-2, $62-66 \mathrm{~cm}$.

1, 2. Laterally compressed specimen showing fibrous posterior projection from capsule.

3. Broken specimen, with distinct projection from posterior of wing.

4. Same specimen showing fibrous wing mesh $(\times 1200)$, interference contrast.

Figures 5, 6 Operculodinium sp.; Sample 274-43-2, 62-66 cm. 5. Focus on archeopyle.

6. Ventral and sectional focus, showing spongose outer wall layer. Both $\times 1000$.

Figures 7-9 Selenopemphix nephroides Benedek; all from Sample $270-43-5,120-123 \mathrm{~cm}$. Figure 8 shows possible shell opening. 


\section{PLATE 5}
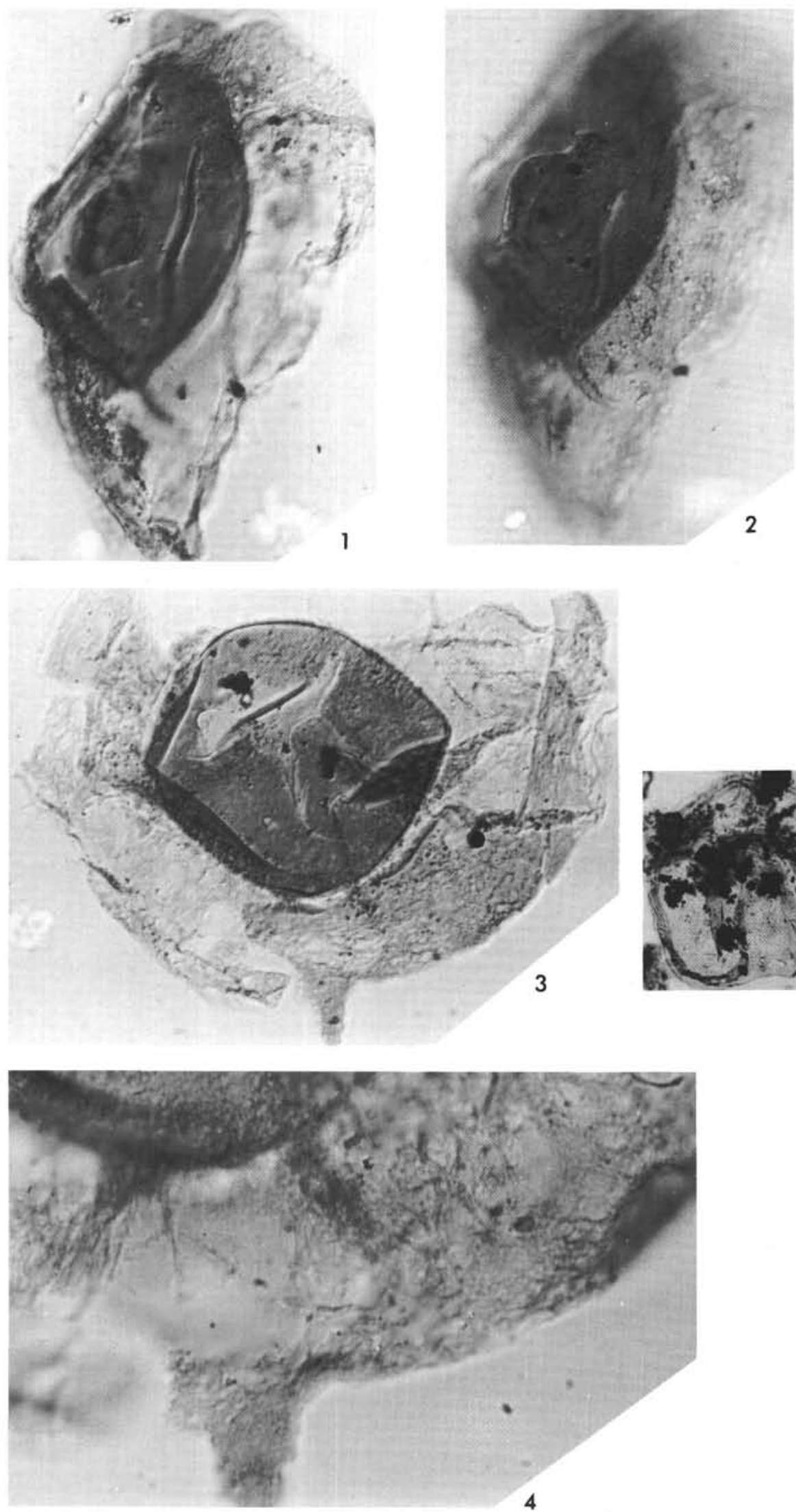
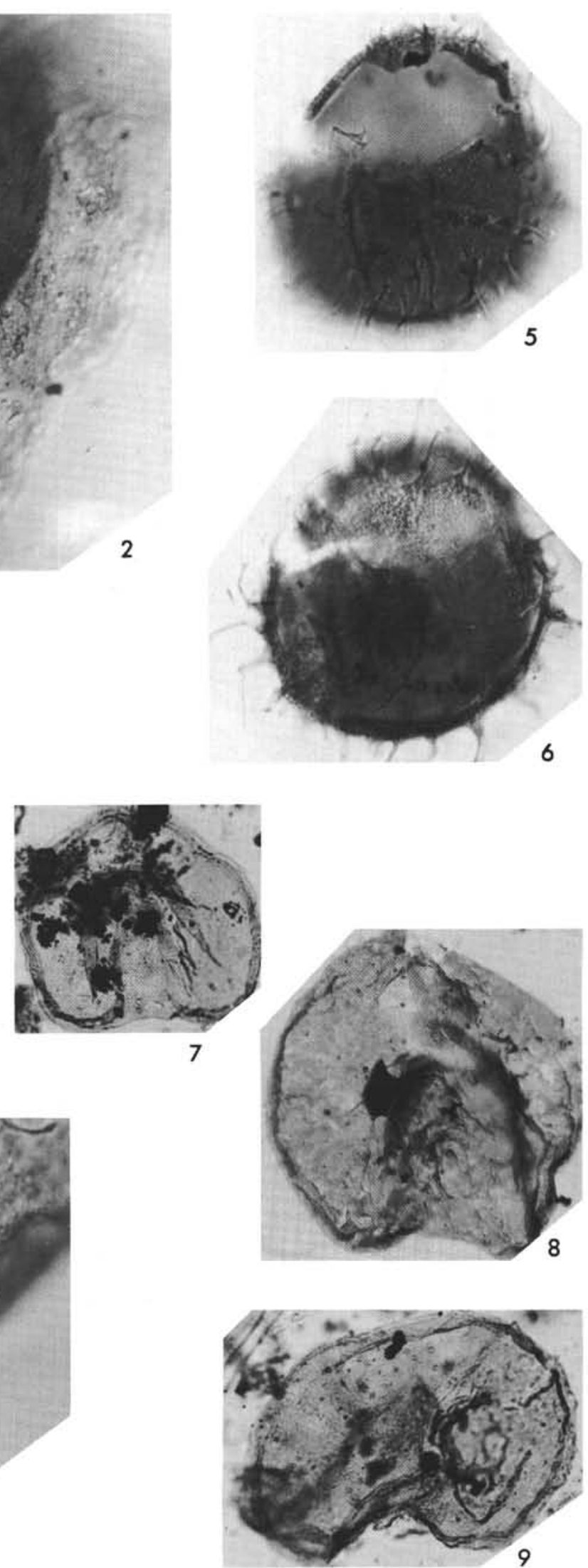


\section{PLATE 6}

All magnifications $\times 1000$ unless stated otherwise.

Figurrres 1-3 Leiosphaeridia sp.; Sample 270-19-3, 136-138 cm.

Figure $4 \quad$ Horologinella sp.; Sample 270-41-13, 87-89 cm.

Figures 5, 6 cf. Dictyosphaeridium deflandrei W. Wetzel.

5. Median focus.

6. Focus on test surface. Sample 274-43-4, 89-90 $\mathrm{cm}$.

Figures 7-9 Tytthodiscus $\mathrm{sp}$.

7. High focus on wall, showing domed protuberances with canals. Sample 270-19-3, 136$138 \mathrm{~cm}$.

8, 9. High and median foci. Sample 270-15-2, 10$20 \mathrm{~cm}$.

Figure $10 \quad$ Stereisporites antiquasporites (Wilson and Webster) Dettmann, Sample 270-42-3, 0-3 cm.

Figure 11 Laevigatosporites major (Cookson) Krutzsch; Sample 270-41-3, 87-89 cm.

Figure 12 allowing two

lines of space

Figure 13 Podosporites microsaccatus (Couper) Dettmann; Sample 270-42-3, 0-3 cm.

Figure 14 Lygistepollenites florinii (Cookson and Pike) Stover and Evans; Sample 270-24-1, 27-37 cm.

Figure 15 Alisporites sp. Sample 270-41-3, 87-89 cm.

Figures 16-21 Nothofagidites spp. 16, 18, 20, N. cf. hetera (Cookson)

18. Interference contrast, $\times 1200$, Sample 270-41$3,87-89 \mathrm{~cm}$.

17. N. matauraensis (Couper), Sample 270-41-3, $87-89 \mathrm{~cm}$.

19. N. cf. vansteensi (Cookson), Sample 270-41-3, $87-88 \mathrm{~cm}$.

21. N. cf. cincta (Cookson), sample 270-19-3, 136$138 \mathrm{~cm}$.

Figures 22, 23 Tricolpites spp.

22. Sample $270-15-2,10-20 \mathrm{~cm}$.

23. Sample 270-43-5, 120-123 cm.

Figures 24, 25 Myrtaceidites spp. Sample 270-41-3, 87-89 cm. 
PLATE 6
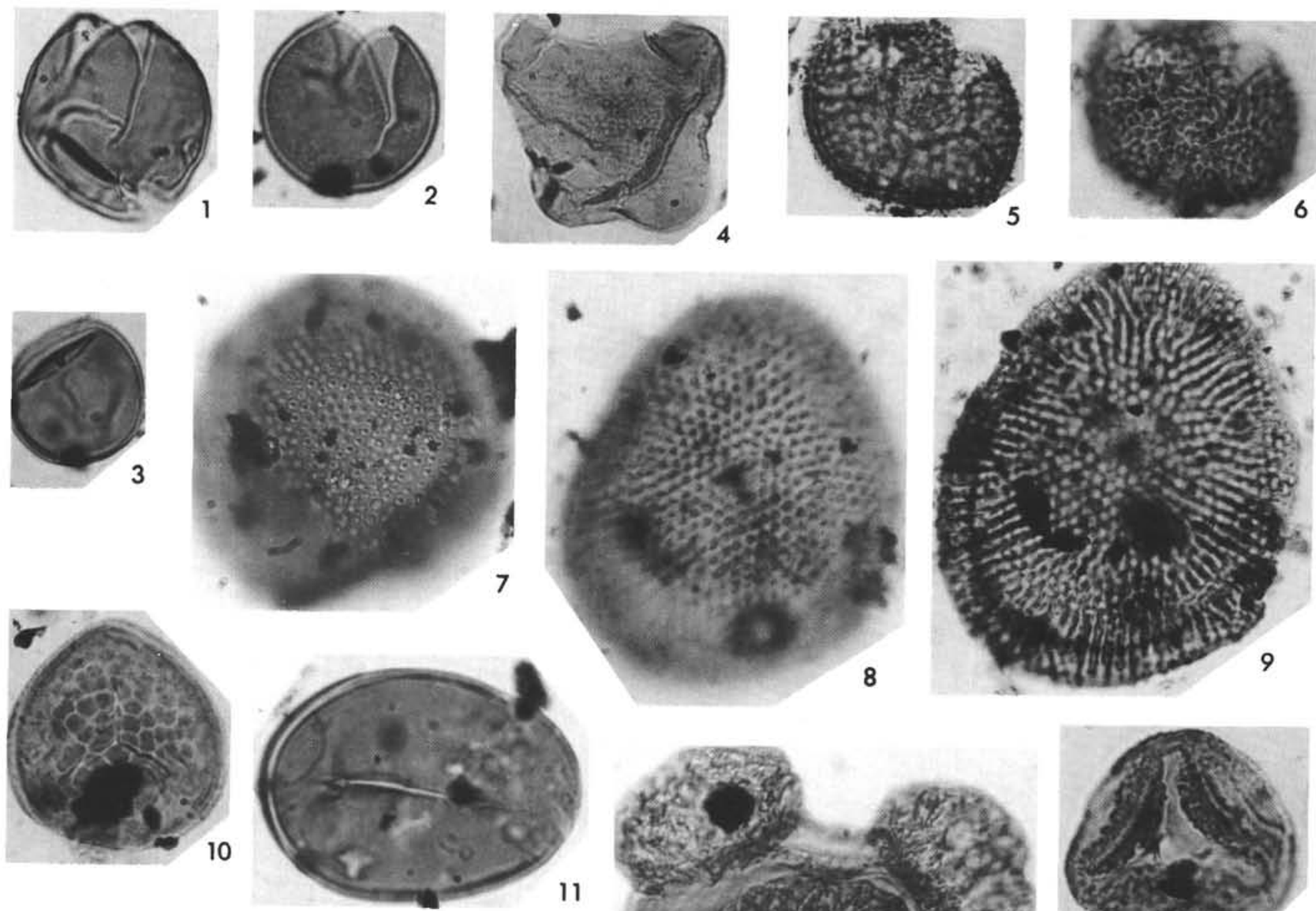

11
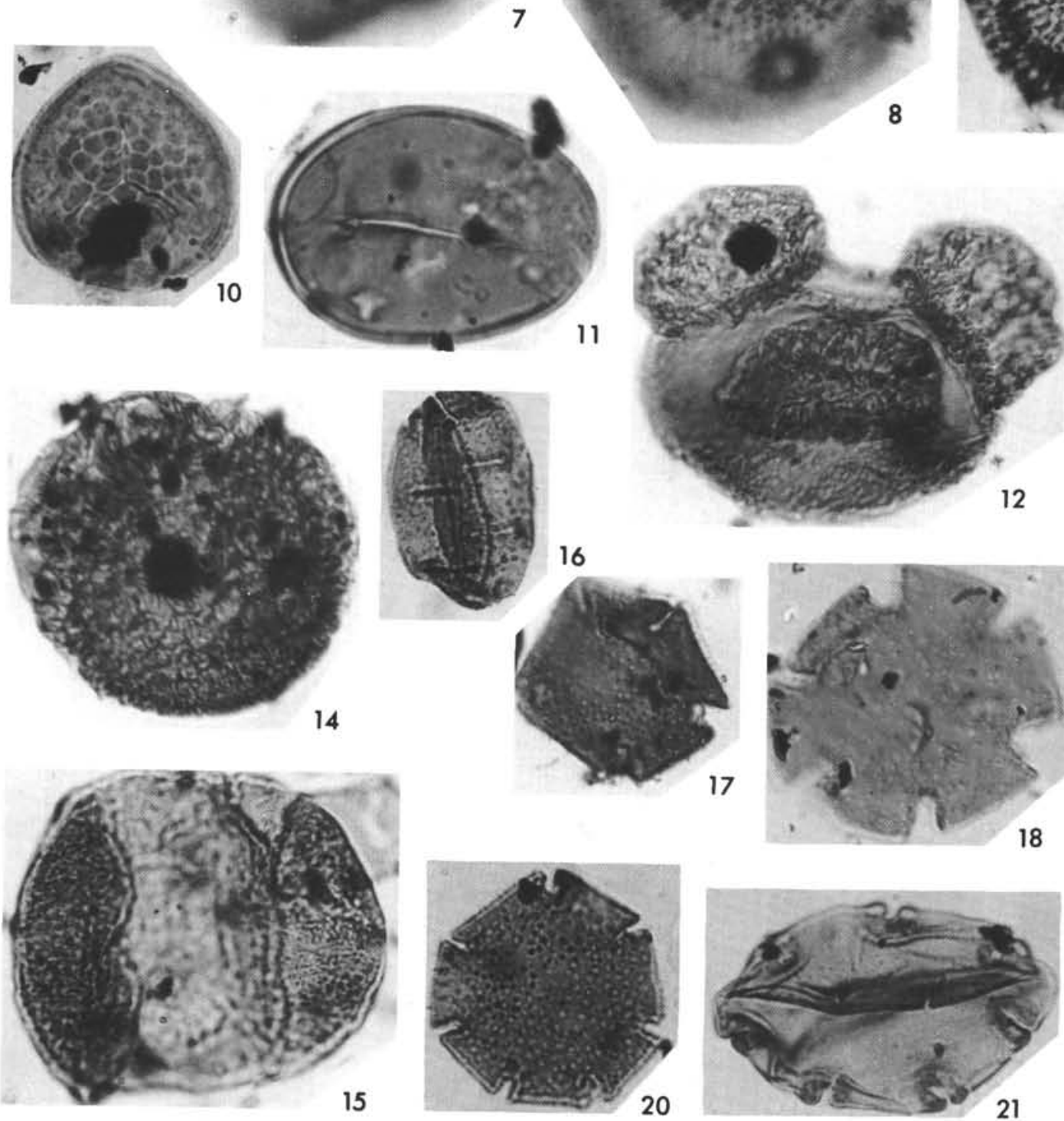
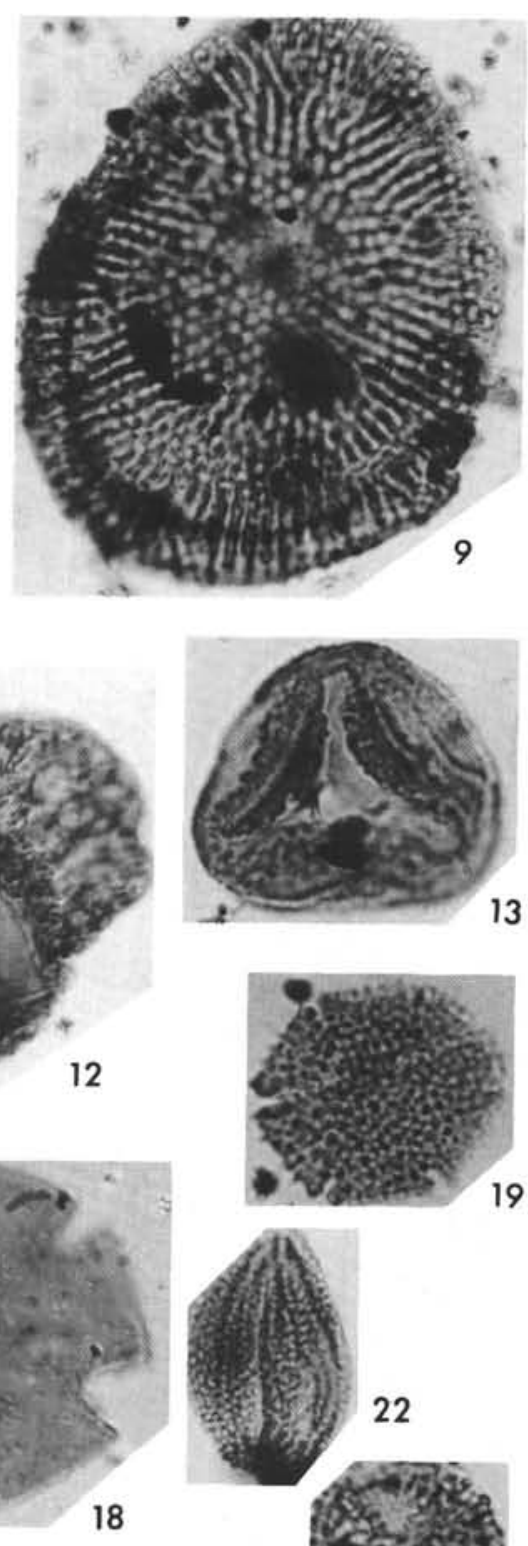

22
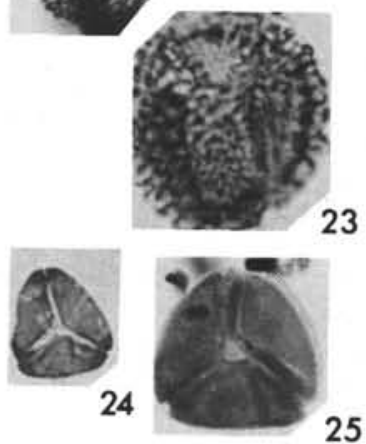


\section{PLATE 7}

All magnifications $\times 1000$.

Figures 1, 2 Proteacidites minimus Couper; Sample 270-42-3, 0$3 \mathrm{~cm}$.

Figures 3, 4 Proteacidites subscabratus Couper; Sample 270-42$3,0-3 \mathrm{~cm}$.

Figures 5, 6 Tricolpites cf. T. fissilis Couper.

5. Sample $270-41-\mathrm{v}, 87-89 \mathrm{~cm}$.

6. Sample .70-42-3, 0-3 cm.

Figure 7 Proteacidites sp.; Sample 270-41-3, 87-89 cm.

Figures 8, 9 Proteacidites cf. P. pseudomoides Stover; Sample 270-25-1, 75-80 cm.

Figure 10 Triporopollenites $\mathrm{sp} .1$; Sample 270-42-3, 0-3 cm.

Figures 11, 12 Triporopollenites sp. 2; Sample 270-41-3, 87-89 cm. 
PLATE 7
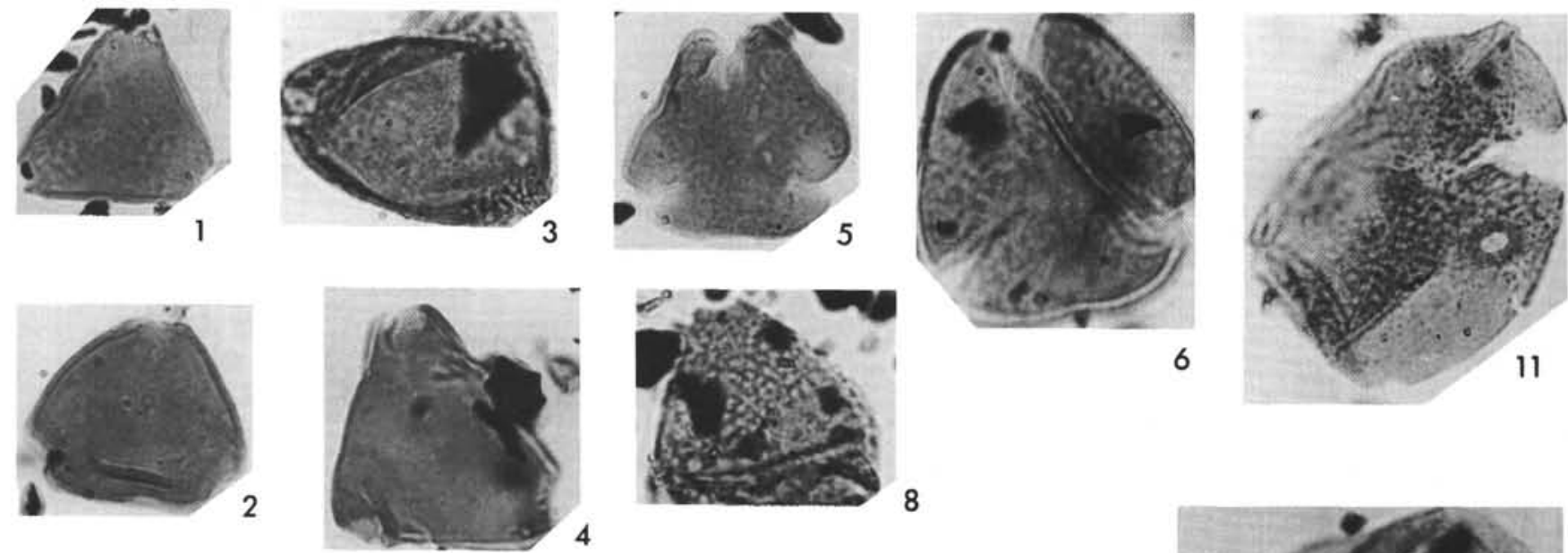

11
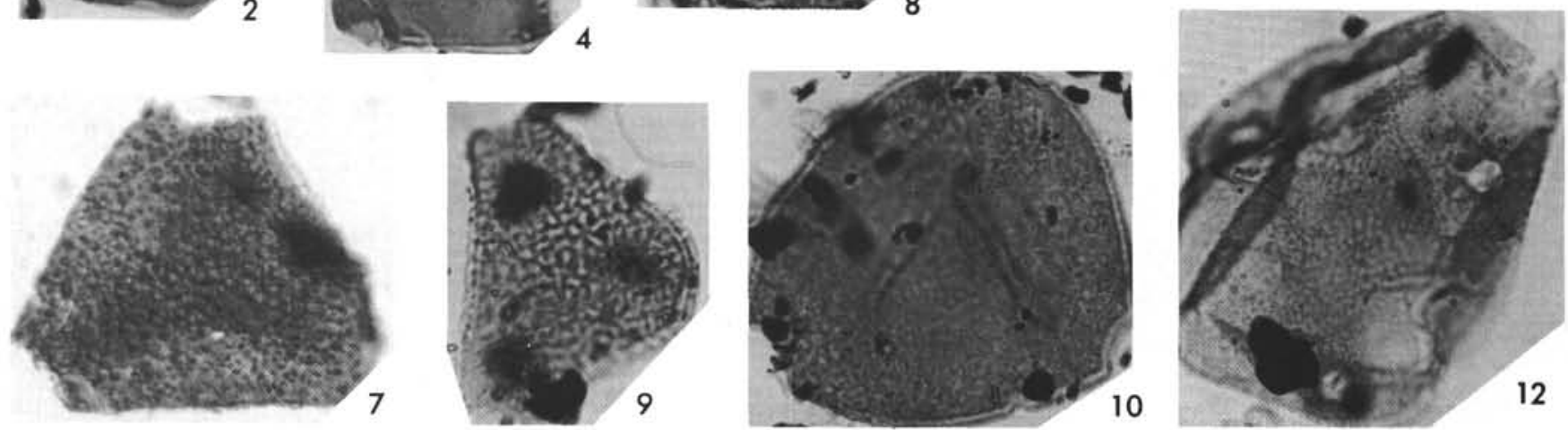